- Collegium Medicum w Bydgoszczy

NATALIA WĄSIK

Okręgowa Izba Radców Prawnych w Olsztynie

TOMASZ KUCZUR

Uniwersytet Kazimierza Wielkiego w Bydgoszczy

\title{
Dochodzenie zapłaty od Narodowego \\ Funduszu Zdrowia za świadczenia zdrowotne udzielane w stanach nagłych \\ - wybrane zagadnienia praktyczne
}

\author{
An court action for payment from the National Health \\ Fund for health benefits provided in emergency \\ - selected practical issues
}

Streszczenie. W publikacji poruszono problematykę dochodzenia przez zakłady opieki zdrowotnej zapłaty od Narodowego Funduszu Zdrowia za świadczenia zdrowotne tzw. ratujące życie. Zagadnieniami, na które zwrócono uwagę, są: możliwość finansowania świadczeń w kontekście limitów określonych umowami o udzielanie świadczeń zdrowotnych, ciężar dowodu udzielenia przez zakłady 
opieki zdrowotnej świadczeń w stanach nagłych, a także potrzeba zasięgania opinii biegłych w tych sprawach w kontekście przesłanek art. 248 § 1 k.p.c.

Słowa kluczowe: świadczenia zdrowotne; stan nagłego zagrożenia zdrowia; proces cywilny; ciężar dowodu; opiniowanie sądowo-lekarskie.

\begin{abstract}
The publication describes the problems of payment seeking by healthcare institutions from the National Health Fund for the so-called "lifesaving health benefits". Issues, which are discussed, include the possibility of health benefits financing in the context of the contract's limits, the burden of proof to provide the health benefits in emergencies, and the necessary of consult experts on these issues in the context of the conditions of Article $248 \S 1$ Polish Civil Procedure Code.
\end{abstract}

Keywords: health care services; health emergency; civil procedure; the burden of proof; medico-legal opinions.

\title{
1. Wprowadzenie
}

Najliczniejszymi sprawami sądowymi, w których stronami postępowania są zakłady opieki zdrowotnej, nie są - jak mogłoby się pierwotnie wydawać - powództwa o odszkodowanie i zadośćuczynienie za tzw. błąd w sztuce lekarskiej, ale sprawy o zapłatę za udzielone pacjentom świadczenia zdrowotne kierowane przeciwko Narodowemu Funduszowi Zdrowia. Każdego roku na wokandy sądowe trafiają do rozpatrzenia setki pozwów, dotyczących różnych zakresów i rodzajów świadczeń zdrowotnych, w tym szeroko pojęte świadczenia nielimitowane oraz tzw. świadczenia ratujące życie pacjentów udzielane w stanach nagłych.

W przedmiocie procesów sądowych o zapłatę za świadczenia zdrowotne ratujące życie pacjentów zagadnieniami budzącymi liczne wątpliwości praktyczne są: możliwość finansowania świadczeń w kontekście limitów określonych umowami o udzielanie świadczeń zdrowotnych, ciężar dowodu udzielenia przez zakłady opieki zdrowotnej świadczeń w stanach nagłych, potrzeba zasięgania opinii biegłych w tych sprawach w kontekście przesłanek art. $248 \S 1$ k.p.c. oraz niezbędność takiej opinii przy rozstrzyganiu o zasadności lub niezasadności roszczenia. 


\section{2. Świadczenia zdrowotne tzw. ratujące życie w kontekście finansowania ochrony zdrowia w Polsce}

Zgodnie z art. 14 ustawy z dnia 27 sierpnia 2004 r. o świadczeniach opieki zdrowotnej finansowanych ze środków publicznych ${ }^{1}$, na zasadach i w zakresie określonych w ustawie podmiotami zobowiązanymi do finansowania świadczeń opieki zdrowotnej ze środków publicznych są właściwi ministrowie lub Fundusz. Natomiast w myśl art. 19 ust. 1 u.ś.o.z. w stanach nagłych świadczenia opieki zdrowotnej są udzielane świadczeniobiorcy niezwłocznie. W ust. 2 tego przepisu doprecyzowano, że w przypadku, gdy świadczenia opieki zdrowotnej w stanie nagłym są udzielane przez świadczeniodawcę, który nie zawarł umowy o udzielanie świadczeń opieki zdrowotnej, świadczeniobiorca ma prawo do tych świadczeń w niezbędnym zakresie. W przedmiocie finansowania świadczeń zdrowotnych ważnym uregulowaniem jest art. 19 ust. 4 u.ś.o.z., zgodnie z którym świadczeniodawca, który nie zawarł umowy o udzielanie świadczeń opieki zdrowotnej, ma prawo do wynagrodzenia za świadczenie opieki zdrowotnej udzielone świadczeniobiorcy $\mathrm{w}$ stanie nagłym. Wynagrodzenie uwzględnia wyłącznie uzasadnione koszty udzielenia niezbędnych świadczeń opieki zdrowotnej. W celu uzyskania wynagrodzenia świadczeniodawca składa wniosek do podmiotu zobowiązanego do finansowania świadczeń opieki zdrowotnej wraz z rachunkiem, wykazem udzielonych świadczeń opieki zdrowotnej i ich kosztów oraz pisemnym przedstawieniem okoliczności udzielenia świadczeń uzasadniających ich sfinansowanie ze środków publicznych (por. art. 19 ust. 5 u.ś.o.z.). Podmiotowi zobowiązanemu do finansowania świadczeń opieki zdrowotnej ze środków publicznych przysługuje natomiast prawo kontroli zasadności wniosku na zasadach określonych w art. 64 u.ś.o.z. (por. art. 19 ust. 6 u.ś.o.z.).

Legalną definicję stanu nagłego zagrożenia zdrowotnego zawiera art. 3 pkt 8 ustawy z dnia 8 września 2006 r. o Państwowym Ratownictwie Medycznym $^{2}$, wyjaśniając, że chodzi tu o stan polegający na nagłym lub przewidywanym w krótkim czasie pojawieniu się objawów pogarszania

\footnotetext{
Dz.U. z 2008 r. Nr 164, poz. 1027 ze zm., dalej: u.ś.o.z.

Dz.U. z 2013r., poz. 757 ze zm.
} 
zdrowia, którego bezpośrednim następstwem może być poważne uszkodzenie funkcji organizmu lub uszkodzenie ciała lub utrata życia, wymagający podjęcia natychmiastowych medycznych czynności ratunkowych i leczenia. W odniesieniu do udzielania świadczeń zdrowotnych pacjentom znajdującym się $\mathrm{w}$ stanie nagłym warto również zwrócić uwagę na brzmienie art. 15 ustawy z dnia 15 kwietnia 2011 r. o działalności leczniczej $^{3}$, zgodnie z którym podmiot leczniczy nie może odmówić udzielenia świadczenia zdrowotnego osobie, która potrzebuje natychmiastowego udzielenia takiego świadczenia ze względu na zagrożenie życia lub zdrowia, a także art. 30 ustawy z dnia 5 grudnia 1996 r. o zawodach lekarza i lekarza dentysty ${ }^{4}$, w myśl którego lekarz ma obowiązek udzielać pomocy lekarskiej w każdym przypadku, gdy zwłoka w jej udzieleniu mogłaby spowodować niebezpieczeństwo utraty życia, ciężkiego uszkodzenia ciała lub ciężkiego rozstroju zdrowia, oraz w innych przypadkach niecierpiących zwłoki.

Pojęcie stanu nagłego było wielokrotnie przedmiotem rozważań sądów powszechnych i administracyjnych. Dorobek orzeczniczy pozwala na sformułowanie tezy, iż stanem nagłym jest stan niespodziewany, do którego nie zaliczają się zabiegi, które wprawdzie ratują życie, są jednak stosowane u chorych leczonych przewlekle, wymagających regularnego poddawania się zabiegom medycznym (np. hemodializy) ${ }^{5}$. Innymi słowy, chodzi tu o przypadek, w odniesieniu do którego istnieje niemożność (przeciwwskazanie) odłożenia (przesunięcia) w czasie pomocy lekarskiej, mogącej według wiedzy i doświadczenia medycznego zapobiec powstaniu u pacjenta niekorzystnych skutków (zagrożenia) dla jego życia i zdrowia. Należy więc uznać, że w pojęcie stanu nagłego obejmuje swoim zakresem pomoc lekarską, która ma zapobiec ciężkim (poważnym) skutkom. W kontekście ziszczenia się przesłanek realizacji świadczenia zdrowotnego w tym trybie istotne znaczenie ma więc „natychmiastowość” i „bezpośredniość”

\footnotetext{
Tekst jedn. Dz.U. z 2013 r., poz. 217, dalej: u.d.l.

Tekst jedn. Dz.U. z 2011 r. Nr 277, poz. 1634 ze zm.

Por. wyrok Sądu Apelacyjnego w Katowicach z dnia 31 lipca 2013r., I ACa 451/13, LEX nr 1369334.
} 
zagrożenia, które uzasadniają niezwłoczne udzielenie pomocy poprzez natychmiastowe udzielenie świadczenia ${ }^{6}$.

W kwestii finansowania świadczeń zdrowotnych tzw. ratujących życie udzielanych pacjentom w stanach nagłych przyjmuje się, że roszczenie o wynagrodzenie przysługuje również podmiotom, które udzieliły takich świadczeń pomimo niezawarcia umowy o świadczenie opieki zdrowotnej. Z tej przyczyny błędne jest twierdzenie, według którego do ubiegania się zwrotu kosztów udzielenia świadczeń zdrowotnych w wypadkach nagłych konieczne jest podpisanie umowy z NFZ ${ }^{7}$.

Przykładem świadczeń zdrowotnych ratujących życie mogą być świadczenia zdrowotne $\mathrm{z}$ zakresu anestezjologii i intensywnej terapii. Zgodnie z §2 pkt 2 rozporządzenia Ministra Zdrowia z dnia 20 grudnia 2012 r. w sprawie standardów postępowania medycznego w dziedzinie anestezjologii i intensywnej terapii dla podmiotów wykonujących działalność leczniczą ${ }^{8}$ pod pojęciem intensywnej terapii rozumieć należy postępowanie mające na celu podtrzymywanie funkcji życiowych oraz leczenie chorych w stanach zagrożenia życia, spowodowanych potencjalnie odwracalną niewydolnością jednego lub kilku podstawowych układów organizmu, w szczególności oddychania, krążenia, ośrodkowego układu nerwowego. Pojęcie to analogicznie definiowało w $\S 1$ pkt 1 rozporządzenie Ministra Zdrowia i Opieki Społecznej z dnia 27 lutego 1998 r. w sprawie standardów postępowania oraz procedur medycznych przy udzielaniu świadczeń zdrowotnych z zakresu anestezjologii i intensywnej terapii w zakładach opieki zdrowotnej ${ }^{9}$. Zgodnie z § 12 rozporządzenia Ministra Zdrowia z dnia 20 grudnia 2012 r. leczenie chorych w ramach intensywnej terapii w szpitalu ma charakter interdyscyplinarny. W razie, gdy stan pacjenta nie wymaga dalszego postępowania w zakresie intensywnej terapii, leczenie przejmują inne oddziały szpitala. Podobnie kwestię tą regulowało rozporządzenie Ministra Zdrowia i Opieki Zdrowotnej z dnia 27 lute-

6 Por. wyroki NSA z dnia 3 października 2012r., II GSK 1369/11, LEX nr 1233974 oraz z dnia 19 kwietnia 2012r., II GSK 318/11, LEX nr 1219015.

7 Por. wyrok Sądu Apelacyjnego we Wrocławiu z dnia 19 stycznia 2012 r., I ACa 1337/11, LEX nr 1164675.

Dz.U. z 2013 r., poz. 15.

9 Dz.U. Nr 37, poz. 215 ze zm. 
go 1998 r., w § 19 ust. 2, wskazując, że świadczenia zdrowotne udzielane w ramach intensywnej terapii dotyczą wyłącznie stanów zagrożenia życia i dopiero gdy stan ten ustanie, leczenie przejmują inne odziały szpitala lub szpital właściwy. Wynika z tego w sposób jednoznaczny, że świadczenia zdrowotne udzielane na oddziale anestezjologii i intensywnej terapii są udzielane wyłącznie w stanach nagłych, nieplanowych, zagrażających bezpośrednio życiu i zdrowiu pacjenta, zaś zakład opieki zdrowotnej nie może ze względów medycznych, etycznych i prawnych (odpowiedzialność cywilna zakładu opieki zdrowotnej i lekarza oraz odpowiedzialność karna lekarza) udzielić świadczeń objętych roszczeniem w innym terminie (pacjenci kwalifikujący się do leczenia w oddziale intensywnej terapii zmarliby, gdyby nie udzielono im świadczeń zdrowotnych z zakresu anestezjologii i intensywnej terapii) lub nie udzielić im świadczeń w ogóle (pacjenci również zmarliby). $W$ tych okolicznościach wątpliwe jest już sam fakt ustalania przez NFZ w umowach o finansowanie świadczeń tzw. limitu dla zakresu anestezjologii i intensywnej terapii, ze względu na niemożność „planowania” liczby świadczeń z tego zakresu oraz prowadzenia systemu kolejkowego dla takich pacjentów.

Z powyższego w sposób jednoznaczny wynika, że limity świadczeń zdrowotnych określonych w umowach o świadczenie opieki zdrowotnej nie mogą skutkować odmową udzielania świadczenia w warunkach zagrażających życiu i zdrowiu, a udzielenie takich świadczeń przez świadczeniodawców stwarza dla nich roszczenie o zapłatę ze środków publicznych wynagrodzenia $^{10}$. Co do świadczeń, do których zaistniała konieczność natychmiastowego ich udzielenia ze względu na przypadek niecierpiący zwłoki, nagły, nieprzewidziany i nieprzewidywalny, siłą rzeczy nie wchodzi w grę możliwość planowania przyjęć, a świadczeniodawca wykonujący je ponad limit określony w umowie może oczekiwać od pozwanego zapłaty należności wyliczonej stosownie do zasad przewidzianych w umowie $^{11}$. Ustawowy obowiązek natychmiastowego udzielenia świadczeń nie

10 Por. wyrok Sądu Apelacyjnego w Rzeszowie z dnia 18 kwietnia 2013 r., I ACa 54/13, LEX nr 1353935.

11 Por. wyrok Sądu Apelacyjnego w Rzeszowie z dnia 4 kwietnia 2013 r., I ACa 20/13, LEX nr 1345566. 
może być zatem limitowany umową, a koszty świadczeń udzielonych ubezpieczonym $\mathrm{w}$ warunkach przymusu ustawowego należy, zgodnie $\mathrm{z}$ art. 56 kodeksu cywilnego ${ }^{12}$, włączyć do skutków, jakie wywołuje umowa zawarta między NFZ a świadczeniodawcą, i obciążyć nimi Fundusz jako podmiot zarządzający środkami publicznymi, z których powinny być one pokryte ${ }^{13}$. Treść stosunku zobowiązaniowego powstałego w następstwie zawarcia umowy o udzielanie świadczeń zdrowotnych z NFZ określają przepisy m.in. art. 19 u.ś.o.z., art. 15 u.d.l. i art. 30 u.z.l., a nie postanowienia umowy ${ }^{14}$. Stosunek prawny, jaki powstaje z umowy zawartej pomiędzy NFZ a świadczeniodawcą, jest zatem z mocy prawa uzupełniony o obowiązek sfinansowania przez NFZ świadczeń tego rodzaju ${ }^{15}$. Nie można też w ramach swobody kontraktowej zawartej w art. $353^{1}$ k.c. nałożyć na zakłady opieki zdrowotnej ponoszenia kosztów świadczeń ponadlimitowych - w tym przypadku świadczeń zdrowotnych ratujących życie pacjentów ${ }^{16}$.

Zasadność punktu widzenia autorów na omówiony powyżej wątek doskonale oddaje stanowisko M. Nesterowicza, który zauważa, że jeżeli zakład opieki zdrowotnej na skutek obowiązku ustawowego z art. 15 u.d.l. będzie sam musiał ponieść koszty leczenia, będzie to oznaczać, że ustawodawca nałożył nań obowiązek świadczeń, nie zapewniając źródła finansowania ${ }^{17}$.

12 Ustawa z dnia 23 kwietnia 1964 r. Kodeks cywilny (tekst jedn. Dz.U. z 2014 r., poz. 121 ze zm.), dalej: k.c.

13 Por. wyrok Sądu Apelacyjnego w Białymstoku z dnia 18 marca 2013 r., I ACa 873/12, LEX nr 1305928 oraz wyroki Sądu Najwyższego z dnia 12 marca 2009 r., V CSK 272/08, LEX nr 530613 i z dnia 16 kwietnia 2008 r., V CSK 533/07, LEX nr 515717.

14 Por. wyrok Sądu Najwyższego z dnia 5 lipca 2007 r., II CSK 141/07, LEX nr 306763.

15 Por. wyrok Sądu Najwyższego z dnia 30 maja 2007 r., IV CSK 60/07, LEX nr 1108516.

16 Por. wyrok Sądu Najwyższego z dnia 12 grudnia 2006 r., II CSK 279/06, LEX nr 445373.

17 Por. M. Nesterowicz, Prawo medyczne. Komentarze i glosy do orzeczeń sqqdowych, Warszawa 2012, s. 505. 


\section{Wątpliwości wokół ciężaru dowodu w sprawach o zapłatę za świadczenia zdrowotne ratujące życie}

Pomimo powyższych, wydawać by się mogło, jasnych i przejrzystych zasad finansowania świadczeń zdrowotnych ratujących życie, stanem permanentnym jest deklarowana przez NFZ odmowa uznania roszczeń zakładów opieki zdrowotnej i zaspokojenia wierzytelności. Jednym ze stałych elementów obrony NFZ przed powództwem jest odwoływanie się do limitów świadczeń, określonych w umowach zawieranych ze szpitalami i zarzucanie szpitalom „niegospodarności” w tym zakresie, tj. niewpisywanie pacjentów w kolejki (również pacjentów oddziałów intensywnej terapii medycznej, w których - jak wiadomo - systemu kolejkowego nie prowadzi się).

Tymczasem, paradoksalnie, przed wniesieniem powództwa o zapłatę, NFZ co do zasady nie kwestionuje okoliczności wykonywania przez szpitale świadczeń zdrowotnych zgodnie z załączanym do pozwów wykazem oraz prawidłowości kwalifikacji tychże procedur medycznych. W tym miejscu dodać trzeba, że NFZ dysponuje ustawowymi instrumentami bieżącej weryfikacji ww. danych.

Sprawozdawanie przez szpitale faktu udzielania świadczeń zdrowotnych w formie raportów statystycznych oraz dokonywanie wszelkich czynności związanych z rozliczeniem tych świadczeń odbywa się w systemie elektronicznym zarządzanym przez NFZ oraz wyłącznie w formie działań dozwolonych przez ten system, stosownie do przepisów rozporządzenia Ministra Zdrowia z dnia 20 czerwca 2008 r. w sprawie zakresu niezbędnych informacji gromadzonych przez świadczeniodawców, szczegółowego sposobu rejestrowania tych informacji oraz ich przekazywania podmiotom zobowiązanym do finansowania świadczeń ze środków publicznych ${ }^{18}$. Wspomnieć należy, że pozwany weryfikuje wykonane świadczenia raportowane przez powoda, a w przypadku jakichkolwiek zastrzeżeń co do poszczególnych świadczeń w stosunku do nich automatycznie

18

Dz.U. z 2008 r., Nr 123, poz. 801 ze zm. 
ustawiana jest procedura korygowania. Sugeruje to zatem, że dane zawarte w Systemie Zarządzania Obiegiem Informacji (SZOI) wykazywane przez NFZ, a załączone przez szpital do pozwów zawierają dane prawdziwe i akceptowane przez Fundusz.

Zgodnie z art. 189 ust. 2 u.ś.o.z. świadczeniodawcy, którzy zawarli umowy o udzielanie świadczeń opieki zdrowotnej, są obowiązani do gromadzenia i przekazywania Funduszowi danych, o których mowa w art. 190 ust. 1 i 2. W myśl $\S 3$ ust. 1 pkt 13a) rozporządzenia Ministra Zdrowia z dnia 20 czerwca 2008 r. w sprawie zakresu niezbędnych informacji gromadzonych przez świadczeniodawców, szczegółowego sposobu rejestrowania tych informacji oraz ich przekazywania podmiotom zobowiązanym do finansowania świadczeń ze środków publicznych rejestr świadczeń obejmuje m.in. następujące dane dotyczące udzielonego świadczenia zdrowotnego - informację, czy świadczenie zdrowotne zostało udzielone w warunkach, o których mowa w art. 19 u.ś.o.z. i art. 15 u.d.l.

W myśl § 10 ust. 3 rozporządzenia Ministra Zdrowia w sprawie zakresu niezbędnych informacji gromadzonych przez świadczeniodawców, szczegółowego sposobu rejestrowania tych informacji oraz ich przekazywania podmiotom zobowiązanym do finansowania świadczeń ze środków publicznych, dane w zakresie wskazanym w rozporządzeniu przekazywane są w formacie elektronicznych komunikatów. Ich przekazywanie (§ 10 ust. 4 rozporządzenia) obejmuje natomiast mogące się powtarzać fazy: 1) przygotowania komunikatu przez świadczeniodawcę, 2) przekazania komunikatu przez świadczeniodawcę, 3) weryfikacji komunikatu przez podmiot zobowiązany do finansowania świadczeń ze środków publicznych, 4) przygotowania przez podmiot zobowiązany do finansowania świadczeń ze środków publicznych komunikatu zwrotnego, zawierającego potwierdzenie prawidłowości komunikatu lub wykaz stwierdzonych w nim błędów i braków, a także 5) przekazanie przez podmiot zobowiązany do finansowania świadczeń ze środków publicznych komunikatu zwrotnego do świadczeniodawcy.

Z powyższego jednoznacznie wynika, że NFZ jeszcze przed wytoczeniem powództwa o zapłatę dysponuje wyczerpującymi danymi na temat udzielanych pacjentom świadczeń zdrowotnych, również świadczeń 
ratujących życie. Co więcej, zobowiązany jest weryfikować te dane na bieżąco przed ich ujęciem w systemie elektronicznym, korzystającym wszak z domniemania prawdziwości zawartych tam informacji. Możliwości systemu elektronicznego używanego przez Fundusz są bardzo szerokie, albowiem NFZ może na etapie weryfikacji raportów wychwycić nawet takie szczegóły jak wykazane usunięcia zęba wcześniej już usuniętego czy hospitalizacja mężczyzny na oddziale ginekologicznym.

Zgodnie z art. 64 ust. 1 u.ś.o.z. podmiot zobowiązany do finansowania świadczeń opieki zdrowotnej ze środków publicznych może przeprowadzić kontrolę udzielania świadczeń świadczeniobiorcom, a w szczególności kontrolę m.in. organizacji i sposobu udzielania świadczeń opieki zdrowotnej oraz ich dostępności, udzielania świadczeń opieki zdrowotnej pod względem zgodności z wymaganiami określonymi w umowie o udzielanie świadczeń opieki zdrowotnej oraz dokumentacji medycznej dotyczącej świadczeń opieki zdrowotnej finansowanych ze środków publicznych. W literaturze podkreśla się, że zasadą jest, że NFZ prowadzi kontrole na podstawie przygotowanych wcześniej i zatwierdzonych na przedstawionych zasadach planów kontroli. Ponadto, w razie potrzeby mogą być podjęte kontrole doraźne poza planem. Kontrole doraźne podejmuje się w przypadku m.in. konieczności zbadania uzyskanych informacji o występujących nieprawidłowościach. W zasadzie więc każda informacja uzyskana przez Fundusz może być powodem wszczęcia postępowania kontrolnego ${ }^{19}$.

W praktyce NFZ w prowadzonym przez siebie SZOI na ogół wykazuje świadczenia zdrowotne ratujące życie jako faktycznie wykonane i zgodne z kwalifikacją art. 15 u.d.l. Na uwagę zasługuje również fakt, że pomimo możliwości wszczęcia postępowania kontrolnego NFZ z reguły nie czyni tego, kwestionując dopiero na etapie sporu sądowego okoliczność udzielania przez szpitale świadczeń zdrowotnych w warunkach ratowania życia pacjentów.

W świetle powyższych okoliczności zastrzeżenia budzi teza wyroku Sądu Apelacyjnego w Krakowie z dnia 15 stycznia 2014 r., I ACa

19 Por. K. Baka, G. Machulak, A. Pietraszewska-Macheta, A. Sikorko, Ustawa o świadczeniach opieki zdrowotnej finansowanych ze środków publicznych. Komentarz, LEX 2010. 
1363/13 ${ }^{20}$ stwierdzającego, iż na zakładzie opieki zdrowotnej, który dochodzi roszczenia o zapłatę za świadczenia medyczne udzielone pacjentom w warunkach zagrożenia życia lub zdrowia, ciąży obowiązek wykazania, że z uwagi na okoliczności poszczególnych przypadków zachodziła potrzeba natychmiastowego udzielenia tych świadczeń. W uzasadnieniu orzeczenia Sąd argumentuje to stanowisko dość lakonicznie, odsyłając do wyroku Sądu Najwyższego z dnia 14 lutego 2008 r., II CSK 532/07²1. Wyrok ten jednak dotyczył dochodzenia przez szpital zapłaty za wykonane pacjentom badania tomografii komputerowej, które - z uwagi na swoją specyfikę - rzeczywiście nie w każdym przypadku udzielane są pacjentom w stanach nagłych (w odróżnieniu np. od procedur wykonywanych w oddziałach intensywnej opieki medycznej). Rozciąganie zatem tego stanowiska na wszystkie świadczenia zdrowotne wykazywane jako ratujące życie należy traktować krytycznie.

Otwartym pytaniem jest katalog środków dowodowych, za pomocą których szpital powinien udowodniać, że udzielił świadczeń zdrowotnych pacjentom w stanach nagłych. Wydaje się, że zaprezentowane wcześniej raporty i sprawozdania NFZ są wystarczającym dowodem oferowanym już na etapie wnoszenia powództwa (okoliczność tę potwierdza często spotykane wydawanie przez sądy nakazów zapłaty w postępowaniu upominawczym właśnie w oparciu o takie materiały). Zauważyć należy, iż zarówno w orzecznictwie, jak i w literaturze podkreśla się, że przyznanie strony złożone $\mathrm{w}$ innej sprawie należy traktować jako przyznanie pozasądowe i ocenić je w związku z całością stanu faktycznego sprawy ${ }^{22}$. W kontekście ewidencjonowania przez NFZ wykonywanych przez zakłady opieki zdrowotnej świadczeń wskazać można na wnioski poczynione przez Sąd Apelacyjny w Katowicach w wyroku z dnia 24 października $2002 \mathrm{r}^{23}$, wedle których faktura jako dokument księgowy, rozliczeniowy i tzw. dowód źródłowy, stwierdzający dokonanie danej operacji gospodar-

\footnotetext{
LEX nr 1540865.

LEX nr 496387.

22 Por. per analogiam wyrok Sądu Najwyższego z dnia 27 kwietnia 1946 r., C I 1099/45, PiP 1946, z. 8, s. 126; T. Demendecki [w:] A. Jakubecki (red.), Kodeks postępowania cywilnego. Komentarz, Warszawa 2008, s. 345.

23 sygn. akt I ACa 219/2002, OSA 2004/2, poz. 6, s. 35.
} 
czej, wystawiony i przyjęty przez kontrahenta (zaksięgowany) bez żadnych korekt i zastrzeżeń daje podstawę do domniemania, że dokonywane w ewidencji księgowej zapisy są odzwierciedleniem rzeczywistego stanu, zgodnie z rzeczywistym przebiegiem zafakturowanej operacji (por. również wyrok Sądu Najwyższego z dnia 6 czerwca 2001 r., sygn. akt V CKN 291/00 ${ }^{24}$ ). Konsekwentnie do linii orzeczniczej przyjmowanie przez NFZ bez żadnych zastrzeżeń komunikatów elektronicznych składanych przez zakłady opieki zdrowotnej powinno rodzić podobne skutki w zakresie procesu dowodzenia również w sprawach sądowych o zapłatę. W orzecznictwie podkreśla się bowiem, że jeśli w sprawie nie można wykazać dokładnie okoliczności mających dla niej istotne znaczenie, sąd może zastosować domniemanie i wyprowadzać je z innych ustalonych faktów. Gdy tego nie zrobił, a było to możliwe, dokonana ocena dowodów była niepełna, co jest poważnym uchybieniem procesowym ${ }^{25}$. Niejednokrotnie w trakcie procesów sądowych NFZ zdaje się kierować postępowanie w stronę negowania prawdziwości danych, ewidencjonowanych bez zastrzeżeń w prowadzonym przez niego systemie zarządzania obiegiem informacji (SZOI). Co więcej, pomimo zaprzeczania argumentom podnoszonym przez dochodzące zapłaty szpitale, NFZ ani nie koryguje ww. danych, ani nie kontroluje tej materii, przez co dochodzi do kuriozalnej sytuacji, w której co innego wynika z pism procesowych pozwanego NFZ, a co innego z prowadzonych przezeń ewidencji elektronicznych. Przypuszczalnie nie ma zatem przeszkód do uznania okoliczności wykonywania przez zakład opieki zdrowotnej świadczeń zgodnie z załączanym do pozwu wykazem, jak również do prawidłowego kwalifikowania przez ten zakład procedur medycznych za okoliczności przyznane przez pozwanego, względnie ich uznanie za udowodnione na zasadzie domniemania faktycznego (art. 231 kodeksu postępowania cywilnego ${ }^{26}$ ).

24 LEX nr 53120.

25 Por. wyrok Sądu Najwyższego z 2006 r., sygn. akt III CSK 174/2006, Gazeta Prawna 2006/225, s. 26.

26 Ustawa z dnia 17 listopada 1964 r. kodeks postępowania cywilnego (tekst jedn. Dz.U. z 2014 r., poz. 101 ze zm.), dalej: k.p.c. 


\section{Dowód z opinii sądowo-lekarskiej w sprawach o zapłatę za świadczenia zdrowotne przeciwko NFZ w świetle art. 248 § 1 k.p.c.}

Niestety, pomimo istnienia możliwości prawnych orzekania w oparciu o wcześniej opisany materiał dowody sądy jako dowód kluczowy dla rozstrzygnięcia zagadnienia udzielenia przez szpitale świadczeń zdrowotnych w stanach nagłych traktują opinie sądowo-lekarskie, które niejednokrotnie wydłużają postępowanie od kilku miesięcy do nawet kilku lat. Wbrew przyjętej linii orzeczniczej co do ciężaru dowodu częstym wnioskodawcą o powołanie w sprawie biegłego jest właśnie pozwany NFZ. Prowadzi to do przykrej konkluzji, że składany przez Fundusz, z reguły w odpowiedzi na pozew, wniosek dowodowy o powoływanie biegłego lekarza o określonej specjalizacji - celem wydania opinii sądowolekarskiej może stanowić próbę realizowania uprawnień kontrolnych wynikających z prawa materialnego na gruncie procesu cywilnego lub stwierdzając bardziej kategorycznie - wyręczanie się sądem w realizacji obowiązków ustawowych. Powszechnie wiadomym jest bowiem argument o braku środków finansowych na prowadzenie przez NFZ kontroli wszystkich podmiotów leczniczych, które zawarły z nim umowę o finansowanie świadczeń opieki zdrowotnej ${ }^{27}$. Truizmem jest $\mathrm{w}$ tej sytuacji podkreślanie, że składany przez pozwanego wniosek dowodowy w istocie prowadzi do znacznego przewleczenia postępowania.

Zgodnie z art. 248 \$1 k.p.c. w wypadkach wymagających wiadomości specjalnych sąd po wysłuchaniu wniosków stron co do liczby biegłych i ich wyboru może wezwać jednego lub kilku biegłych w celu zasięgnięcia ich opinii. Co prawda okoliczność, „czy w danych okolicznościach, w odniesieniu do konkretnego pacjenta, zakład opieki zdrowotnej udzielił świadczenia w warunkach ratowania życia” może w pewnych okolicznościach wpisywać się w pojęcie „wiadomości specjalnych”, o których mowa w art. 248 k.p.c., niemniej jednak obwarowane jest to kilkoma warun-

27 Informacja o wynikach kontroli. Realizacja zadań Narodowego Funduszu Zdrowia w ramach planu finansowego na 2013 r., Najwyższa Izba Kontroli, 28 października 2014 r., KZD-4101-001-01/2014. 
kami. Użycie przez ustawodawcę terminu „wypadek” w odniesieniu do sytuacji generującej obowiązek powołania biegłego wskazuje jednoznacznie na konkretną sytuację, indywidualny przypadek, okoliczność ściśle skonkretyzowaną, wyjątkową, co do której zachodzą określone wątpliwości. Tymczasem w procesach o zapłatę przeciwko NFZ „wypadek wymagający wiadomości specjalnych”, mający uzasadniać konieczność zasięgnięcia opinii biegłego, często sprowadzany jest do roli weryfikacji prawidłowości określenia przez powoda wartości przedmiotu sporu i jego zakresu. W zdecydowanej większości postępowań u podstaw wniosku dowodowego NFZ o powołanie w sprawie biegłego jest założenie a priori o niezaistnieniu przy udzielaniu świadczeń opieki zdrowotnej przesłanek określonych w art. 15 u.d.l. Z tej przyczyny biegli - lekarze zmuszeni są odpowiadać na ogólne, lakoniczne pytania, czy powodowy zakład opieki zdrowotnej wykonywał wskazane w pozwie świadczenia zgodnie z przedstawionym wykazem, czy prawidłowo kwalifikował procedury medyczne i czy istnieją podstawy do przyjęcia, że świadczenia te udzielone zostały w warunkach ratowania życia pacjentów. Zasadnym wydaje się stwierdzenie, że pierwsze i drugie pytanie dotyczy materii, która wchodzi w sferę zagadnień administracyjnych i stricte technicznych, a ich rozstrzygnięcie nie wymaga wiedzy i doświadczenia medycznego. Argument ten dodatkowo wzmacnia okoliczności braku wcześniejszego kwestionowania danych przez pozwany NFZ, który dysponując ustawowymi instrumentami ich weryfikacji, nie uznał za konieczne wdrożenie odpowiednich w tym zakresie procedur. Na aprobatę zasługuje w tym względzie zgłaszany w piśmiennictwie pogląd, że ocena, czy pacjent pozostaje w takiej właśnie sytuacji, należy w zasadzie do osób wykonujących zawód medyczny zatrudnionych w podmiocie leczniczym (niezależnie od podstawy zatrudnienie), a ściślej - do uprawnionego lekarza ${ }^{28}$. Decyzje co do leczenia takiego pacjenta podejmowane są na ogół w trybie pilnym, pod silną presją, w czasie rzeczywistym. Nie kwestionując w tym względzie wartości dowodowej opinii sądowo-lekarskiej, dostrzec należy, że dokumentacja

28 T. Rek, Komentarz do art.15 ustawy o działalności leczniczej [w:] M. Dercz, T. Rek (red.), Ustawa o działalności leczniczej. Komentarz, LEX 2013. 
medyczna, na podstawie której biegły wydaje opinię, powyższych dramatycznych okoliczności nigdy w pełni nie oddaje.

\section{Wnioski}

Dochodzenie przez zakłady opieki zdrowotnej zapłaty za udzielenie świadczeń zdrowotnych pacjentom znajdującym się w stanach nagłych nie jest uzależnione od uprzedniego zawarcia przez ten podmiot z NFZ umowy o udzielanie świadczeń zdrowotnych. Finansowanie tego typu świadczeń nie wynika bowiem ze zobowiązań umownych, ale z ustawowych zadań stawianych przed podmiotami leczniczymi, specyfiki działalności leczniczej, a także zasad wykonywania zawodów medycznych.

Ciężar dowodu w sprawach o zapłatę przeciwko NFZ powinien kształtować się odmiennie w sytuacji, w której roszczeń dochodzi szpital mający podpisaną umowę z Funduszem na udzielanie świadczeń zdrowotnych, a inaczej w przypadku, w którym świadczenia udzieli podmiot, którego nie wiąże taka umowa z NFZ (np. lekarz prowadzący prywatną praktykę). Podmiot, który umowę z Funduszem zawarł, ma pełne prawo powoływać się przy uzasadnieniu swoich twierdzeń na dowody elektroniczne w postaci danych ewidencjonowanych i zatwierdzanych bez zastrzeżeń przez NFZ. Utrzymywanie się tego stanu można poczytywać w kategoriach przyznania prawdziwości argumentacji powoda. Można bowiem przyjąć, że gdyby NFZ, mający świadomość wystąpienia przez szpital o zapłatę za te świadczenia, przeprowadził kontrolę prawidłowości udzielania świadczeń zdrowotnych i na tym etapie je zakwestionował, powództwo nie zostałoby w ogóle wniesione, tudzież mogłoby być ograniczone.

Dowód z opinii sądowo-lekarskiej nie powinien być traktowany w kategoriach dowodu koronnego w omawianej kategorii spraw. Co więcej, nie sposób uznać, by kwestia właściwego rozliczania procedur medycznych ratujących życie, w sytuacji, w której NFZ jest podmiotem w tym zakresie wyspecjalizowanym, dysponującym szerokim zapleczem organizacyjnym i medycznym, wymagała wiadomości specjalnych. Naturalnie nie przekreśla to możliwości powoływania w sprawach o zapłatę od NFZ biegłych, niemniej wniosek dowodowy powinien być starannie przygoto- 
wany. Jeżeli więc roszczenie obejmuje kilka-kilkadziesiąt świadczeń zdrowotnych, NFZ musi dokładnie określić, dlaczego jego zdaniem dane świadczenie nie może zostać zakwalifikowane jako udzielone w stanie nagłym, czy innymi słowy - które badanie (etap diagnostyczny lub terapeutyczny) kwestionuje. Niedopuszczalnym jest powoływanie biegłego przy założeniu a priori, że szpital w ogóle nie udzielał świadczeń w warunkach ratujących życie. Przestrzeganie tych zasad pozwoli wyeliminować sytuacje, w których NFZ „z klucza” podważa zasadność udzielania przez szpitale świadczeń nawet tym pacjentom, którzy ostatecznie zmarli, skróci czas wydania opinii sądowo-lekarskiej i uprości - jak się wydaje postępowanie dowodowe w omawianych sprawach.

\section{Bibliografia:}

Baka K., Machulak G., Pietraszewska-Macheta A., Sikorko A., Ustawa o świadczeniach opieki zdrowotnej finansowanych ze środków publicznych. Komentarz, LEX 2010.

Demendecki T. [w:] A. Jakubecki (red.), Kodeks postępowania cywilnego. Komentarz, Wolters Kluwer Polska, Warszawa 2008.

Nesterowicz M., Prawo medyczne. Komentarze i glosy do orzeczeń sqdowych, Lexis Nexis Polska, Warszawa 2012.

Rek T., Komentarz do art. 15 ustawy o działalności leczniczej, [w:] M. Dercz, T. Rek (red.), Ustawa o działalności leczniczej. Komentarz, LEX 2013. 